\title{
Genetic resources of fodder crops in Croatia: current state and future prospects
}

\author{
Aleš Vokurka ${ }^{1 *}$, Tihomir C̆upić $^{2}$, Leonarda Sigal ${ }^{1}$, Hrvoje Kutnjak $^{1}$, Dubravka Dujmović \\ Purgar $^{1}$, Snježana Kereša ${ }^{1}$, and Snježana Bolarić $^{1}$ \\ ${ }^{1}$ Faculty of Agriculture, University of Zagreb, 10000 Zagreb, Croatia \\ ${ }^{2}$ Agricultural Institute Osijek, 31000 Osijek, Croatia
}

\begin{abstract}
Plant breeding as an important discipline in agriculture started in Croatia during the last decades of XIX century at several institutions and farms, but was mainly focused on arable grains, but to less extent to fodder, and other crops. The efforts in the research, collecting and evaluation of genetic resources of fodder crops started in the second half of XX century, but were interrupted and ceased by the war in 1990-ies, with a part of material being lost. The activities started almost from scratch by establishing the Croatian Gene Bank in early 1990ties that existed only for few years. A new National Plant Gene Bank was established in 2004 as a network working in synergy with the SEEDNet programme, and was directed by National Plant Genetic Resources Programme based on the valid international treaties on biodiversity, and conducted according to good practice in genetic resources maintenance and research, with the support of the Ministry of Agriculture and EU funds. The paper presents the short outline of the research of the genetic resources of fodder crops.
\end{abstract}

\section{Introduction}

The size of Croatia is relatively small to European ranges $\left(56.594 \mathrm{~km}^{2}\right)$, but it still has a huge variability in natural conditions, including climate zones, relief, soils, and vegetation. The two main climate zones are hot- or warm-summer Mediterranean climate (Csa, Cfa and $C f b$ ) according to Köppen classification), and hot- or warm-summer humid continental climate $(D f a, D f b)$ in the continental regions and regions higher than $500 \mathrm{~m}$ above sea level, the latter with the pocets of mountainous boreal climate conditions $(D f c)$ in small areas above $1000 \mathrm{~m}$ above sea level. The climatic conditions in Croatia could be classified into 19 subtypes of $\mathrm{C}$ and $\mathrm{D}$ climate types, which is wide range in comparison to relatively small country [1]. Such natural conditions predetermine the variety of agricultural systems and production niches, including horticultural production (fruits and vegetables), arable crop production, fodder crops and livestock production. A huge range of natural conditions, unusual relief structure, complex geological history and relatively unspoiled and preserved areas [2] also make a rich basis for biodiversity, and investigation, evaluation and preservation of prospective accessions in gene banks, and their inclusion into breeding

\footnotetext{
* Corresponding author: avokurka@agr.hr
} 
programmes. Having in mind all the aspects of importance of genetic resources, such as mitigating genetic erosion, conservation and maintaining "primitive" varieties and genotypes of value for the future, using genetic resources in plant breeding, [3] systematic steps has been taken on administrative, legal, research and strategic level.

\section{Historical overview of activities related to plant genetic resources of fodder crops}

Collecting and maintenance of the germplasm of agricultural plants has a tradition of almost 130 years, and starts at the former Royal Agriculture and Forestry College (today's College of Agriculture) in 1893 when the Station for the research of seeds was established within the college. Similar activities, related to arable crops, mainly maize and wheat were carried out also at huge farms in the beginning of XX century. The first collection of the primitive grains and pulses was established at the Faculty of Agriculture in Zagreb in 1921. but only after the WW2, the work at germplasm investigation and plant breeding had been undergoing through a new impulse. However, it was focused mainly at arable crops and industrial plants, and less to fodder crops and grasses, with fruits and vegetables almost excluded from the focus of then time's breeders. Two institutes initiated breeding programme of alfalfa and red clover: Agricultural Institute in Osijek, and BC Institute in Zagreb [4]. Both institutes maintained collections of alfalfa cultivars, and grasses [5] but were also conducting breeding programmes of red and white clover, and bird's-foot trefoil (L. corniculatus L.). These efforts started with collecting introduced and commercial germplasm, but also autochthonous genotypes [6] that might improve the traits appropriate for local conditions. At the time of post-WW2 Yugoslavia, the BC Institute in Zagreb was also maintaining the collection of grass ecotypes and native grass populations. Yugoslavia was also a member of European Cooperative Programme for Genetic Resources (ECP/GR) since 1979. The most systematic research of genetic resources was commenced in 1987. by the initiation of the comprehensive project "Plant Gene Bank of Yugoslavia" for all economic plants, but was ceased soon by disintegration of the federal state. Though, expeditions were undertaken within the fodder crops division of the project, with the focus on Lotus sp., Trifolium sp., Medicago sp. and several grasses, mainly in continental part of Croatia, with the guidelines for establishing the basic collection, active collection, and archive of the sample donors before the termination of the activities due to war [7].

\subsection{Establishing the first gene bank (1991-2004)}

After the disintegration of Yugoslavia, the Croatian Plant Genes Bank was established in 1991 at the Faculty of Agriculture, University of Zagreb. There were three levels of the plant gene collection: safe, basic, active, and work collection. Safe collection was organized according to the principles of FAO/IPGRI. The basic collection was established at the Faculty of Agriculture in Zagreb, but the active collections were maintained at various research and breeding institutions in Croatia [7]. Fodder crops and legumes collection of 68 accessions of grasses and legumes was maintained at the Faculty, as a constituent among 14 different divisions of the gene bank organized according to the crop type. The lack of funds after few years was a huge obstacle for further maintenance and collecting, and this collection ceased to work. However, in 1993. Croatia accessed the ECP/GR programme as the first step in internalization of the actions related to genetic resources. 


\subsection{National Programme for Plant Genetic Resources (2004 - 2017)}

In 2004. a new National Bank of Plant Genes was founded as a network of institutions. It started to operate in a synergy with the SEEDNet programme funded by the Swedish International Development Agency, Swedish Biodiversity Centre and NordGen. SEEDNet was a network of 12 countries from SE Europe established for the period of ten years, supporting long-term conservation and sustainable utilisation of genetic resources, training courses and first expeditions. It was for the first time to have a specific working group for fodder crops which continue to exist until now, besides five other WGs.

The Government of Croatia recognized the strategic importance of the plant genetic resources of agricultural plants, according to the actual trends in the world [8], including the resources of fodder crops which had been considered as almost marginal in comparison to other "big" crops. In 2006 Ministry of Agriculture put the National Plant Gene Bank network under the steering of the newly established Committee for Plant Genetic Resources (CPGR) which propose the recurring action plans (National Programme for Plant Genetic Resources) for subsequent periods of five years with strictly determined activities, such as inventory-making, collecting, ex situ and in situ conservation, description and research guidelines, building of storage capacities, establishing regulatory frameworks, and setting up principles for dissemination of information $[9,10]$.

In 2009 Croatia accepted the International Treaty for Plant Genetic Resources in Food and Agriculture (ITPGRFA), and joined the AEGIS, the European Genebank Integrated System of gene bank maintenance within the framework of ECPGR, maintaining collections under specific standards of quality and expertize, and has free access according to international regulations. In 2009 Croatia also joined the EURISCO, a database based on the national gene bank networks. In further steps of integration to international treaties, Croatia signed the Nagoya Protocols which ensures fair access to genetic resources and fair distribution of the gains derived therein. The activities of WG Fodder Crops from 2004 when established until now are shared among three institutions: Faculty of Agriculture, BC Institute (both in Zagreb), and Agricultural Institute in Osijek, and were complementary to the SEEDNet activities [10]. In the period 2004 - 2006 activities were focused to de novo establishment of the physical collections of fodder crops and grasses, and regeneration of 617 accessions documented in previous periods and projects (1980ties and 1990ties). Majority of these accessions, mainly commercial cultivars and breeding lines, proofed nongerminating and were lost. The period 2007.-2010. introduced the collecting expeditions in order to extend the accession basis, mainly to the regions with marginal climate conditions which could provide germplasm for breeding for natural stresses associated with climate change, but also to the rural regions with diminishing production - meadows and pastures previously used, but neglected with the time. The main activities continued (regeneration, evaluation), but were extended with the procurement of laboratory equipment for all the institutions except BC Institute which dropped off from the programme in 2017. In the period 2014-17 the collecting expeditions and other activities continued, but also included the establishment of safe collection held at the facility of Centre for Seed and Seedlings (Croatian Agency of Agriculture and Food).

\subsection{Current state and prospects for future (after 2017)}

Until now, the project already entered the routines phase with all standard tasks [10], but it has been periodically extended by other activities, such as the analysis of wild relatives, abundance and conditions of their populations, determine the geographic areas exceptionally abundant with the biodiversity of wild relatives, and if it is justified, include them into collections. The exceptional focus has been directed to M. falcata L. in its natural 
habitats that are endangered. In situ and on farm conservation and management of fodder crops biodiversity has got an importance for future breeding programmes for biotic and abiotic stresses arisen from climate changes. The priority fodder legumes and grasses are shown in Table 1. The current state of the accessions (the inventory) is shown in the Table 2.

Table 1. The legumes and grasses identified as priority for genetic resources conservation

\begin{tabular}{|c|c|}
\hline Fodder legumes & Fodder grasses \\
\hline Medicago sativa $\mathrm{L}$. & Agrostis spp. \\
\hline Medicago falcata $\mathrm{L}$. & Arrhenatherum elatius (L.) P. Beauv. ex J. \\
\hline Medicago x varia Martyn & Presl \& C. Presl \\
\hline Trifolium pratense $\mathrm{L}$. & Bromus spp. \\
\hline Trifolium repens $\mathrm{L}$. & Dactylis glomerata L. \\
\hline Trifolium incarnatum $\mathrm{L}$. & Festuca rubra $\mathrm{L}$. \\
\hline Lotus corniculatus L. & Festuca arundinacea Schreb. \\
\hline Onobrychis viciifolia $L$. & Festuca pratensis Huds. \\
\hline Pisum sativum $\mathrm{L}$. & Phleum pratense $\mathrm{L}$. \\
\hline Vicia sativa $\mathrm{L}$ & Lolium perenne $\mathrm{L}$. \\
\hline Vicia vilosa $\mathrm{L}$. & Lolium multiflorum Lam. \\
\hline
\end{tabular}

Table 2. The current state of the accessions of fodder crops and grasses maintained within the network of the National Bank of Plant Genes (HRV021 = Agricultural Institute, Osijek; HRV041 = Faculty of Agriculture, Zagreb, HRV053 = Centre for Seed and Seedlings, Osijek)

\begin{tabular}{|l|c|c|c|c|}
\hline & \multicolumn{4}{|c|}{ No. of accessions } \\
\hline Plant species & HRV021 & HRV041 & HRV053 & Total \\
\hline $\begin{array}{l}\text { Arrhenatherum elatius (L.) P. Beauv. } \\
\text { ex J. Presl \& C. Presl }\end{array}$ & & 11 & & 11 \\
\hline Beta vulgaris L. & & & 3 & 3 \\
\hline Brassica napus L. subsp. napus & & & 1 & 1 \\
\hline $\begin{array}{l}\text { Brassica napus } \text { L. subsp. rapifera } \\
\text { Metzg. }\end{array}$ & & & 2 & 2 \\
\hline Brassica oleracea L. & & & 1 & 1 \\
\hline Cicer arietinum L. & 4 & & & 4 \\
\hline Dactylis glomerata L. & & 26 & & 26 \\
\hline Daucus carota L. & & & 1 & 1 \\
\hline Festuca arundinacea Schreb. & & 10 & 1 & 11 \\
\hline Festuca pratensis Huds. & & 2 & & 2 \\
\hline Festuca rubra L. & & 1 & & 1 \\
\hline Lathyrus sativus L. & 4 & & & 4 \\
\hline Lolium multiflorum Lam. & & 4 & & 4 \\
\hline Lolium perenne L. & & 1 & & 1 \\
\hline Lotus corniculatus L. & & 3 & 1 & 4 \\
\hline Lupinus albus L. & & & 2 & 2 \\
\hline Medicago falcata L. & & 3 & & 3 \\
\hline Medicago $x$ varia Martyn & & 1 & & 1 \\
\hline Medicago sativa L. & & 10 & 7 & 17 \\
\hline Phalaris canariensis L. & & 1 & & 1 \\
\hline Phaseolus vulgaris L. & & & & 2 \\
\hline Phleum pratense L. & & & & 2 \\
\hline Pisum sativum L. & & & 10 & 14 \\
\hline Raphanus sativus L. & & &
\end{tabular}




\begin{tabular}{|l|c|c|c|c|}
\hline Trifolium pratense L. & & 59 & 3 & 62 \\
\hline Trifolium repens L. & & 3 & 1 & 4 \\
\hline Trisetum flavescens (L.) P. Beauv. & & 10 & & 10 \\
\hline Vicia faba L. & 2 & & & 2 \\
\hline Vigna radiata (L.) R. Wilczek & 1 & & & 1 \\
\hline Vigna unguiculata (L.) Walp. & 2 & & & 2 \\
\hline Ukupno & 19 & 147 & 34 & $\mathbf{2 0 0}$ \\
\hline
\end{tabular}

\section{Conclusion}

After the first attempts in the period of Yugoslavia and stagnations during the disintegration of the federal state, activities related to the genetic resources of fodder crops have been laid on solid foundation during the last two decades. The advancements are achieved in institutional, legal and infrastructural level. Professionals have acquired valuable experience through their work and international collaboration. The government, recognizing the strategic importance of genetic resources introduced the appropriate legal frame, and set up the conditions for strategic long-term activities and further international cooperation. The WG for fodder crops had been formed, including three institutions (reduced to two), within the National Programme for Plant Genetic Resources which is the main channel for implementing the actions, including building infrastructure for ex situ and in situ gene banks, and setting up future goals and strategy. Within the network 200 accessions has been maintained until now, which is relevant number, taking into account the size of the country and relatively recent initiation of the actions.

\section{References}

1. S. Kovačić, T. Nikolić et al., Flora jadranske obale i otoka (Školska knjiga, Zagreb, 2008)

2. I. Penzar, B. Penzar, Agroklimatologija (Školska knjiga, Zagreb, 1985)

3. S. Peres, Studies in History and Philosophy of Modern Physics, 55 (2016)

4. S. Halagić, S., V. Kozumplik, Krmne leguminoze. 377-394, in: Oplemenjivanje bilja (Agronomski fakultet, Zagreb \& Poljoprivredni fakultet Osijek, 1996)

5. S. Popović, T. Ćupić, M. Tucak, S. Grljušić, S. Bolarić, T. Ivanušić, Krmno bilje, in: Oplemenjivanje poljoprivrednog bilja u Hrvatskoj, I.Pejić, V. Kozumplik (eds)

(University of Zagreb, Faculty of Agriculture, Zagreb, 2012)

6. V. Kozumplik, Z. Martinić-Jerčić, Agric. Conspec. Sci. 65(2) (2000)

7. I. Kolak, Z. Šatović. Sjemenarstvo 12(95)6 (1995)

8. N. I. Dzyubenko, Biopreserv. Biobank. 16(5) (2018)

9. S. Bolarić, M. Culek, T. Čupić, Conservation of genetic resources of fodder crops in Croatia, in Books of Abstracts of the International Meeting Plant Breeding, Seed and Nursery Production, 11-13 November, Sveti Martin na Muri, Croatia (2015)

10. Government of the Republic of Croatia. National programme of conservation and sustainable utilisation of plant genetic resources in food and agriculture in the Republic of Croatia for the period 2017-2020 (2017) 